\title{
Kunci Kebahagiaan
}

Victor Christianto, http://www.sci4God.com

Teks: Kej. 32:22-31; Luk. 18:1-8

Shalom, selamat pagi saudaraku. Kemarin pagi (17/10) saya memperoleh kehormatan untuk berkhotbah dalam acara ibadah di salah satu Lapas. Tema khotbah yang saya angkat adalah: Kunci kebahagiaan. Saya posting secara utuh di sini, mungkin berguna bagi pembaca yang lain.

Pembuka

Shalom, bapak-bapak dan adik-adik yang dikasihi Tuhan.

Siapakah di antara kita yang ingin bahagia? Tolong angkat telunjuk sekarang.

Nah, kini bayangkanlah malaikat Gabriel datang dalam mimpi kepada Anda, dan berkata: "Tuhan telah mendengar seru doamu dan Ia berkenan mengabulkan satu permohonanmu apapun itu. Nah, pikirkanlah dengan bijak."

Lalu Anda terbangun dari mimpi, nah kini saya beri waktu 5 menit untuk memikirkan apakah yang Anda ingin minta kepada Tuhan? Bagi orang Indonesia seperti kita, pasti ingat pepatah kuno bahwa banyak orang yang mencari harta, tahta, dan wanita.

Apakah bagi Anda bahagia itu berarti memiliki 4 bunker berisi beberapa trilyun uang tunai seperti yang dikabarkan dimiliki oleh Dimas Kanjeng? Atau memiliki tahta kekuasaan bagai presiden Amerika Serikat? Atau hidup dikelilingi banyak perempuan cantik? Mari kita renungkan 5 menit... 
Yakub

Dari bacaan kita Lukas 18, dijelaskan bagaimana kita mesti berdoa tidak jemu-jemu. Tapi sebelum kita berdoa tanpa jemu, tahukah kita apakah yang ingin kita minta itu memang terbaik untuk hidup kita?

Mari kita tengok kisah hidup Yakub. Menurut Alkitab, ia adalah saudara kembar Esau. Dikisahkan dalam Kej. 25 bahwa ketika lahir, ia memegang tumit Esau, dan itulah sebabnya ia diberi nama Yakub. Ungkapan "memegang tumit" itu kalau tidak keliru juga berkonotasi penipu dalam budaya Yahudi kuno.

Dan memang sepanjang hidupnya, Yakub sering menggunakan akal bulusnya untuk mendapatkan berbagai hal, termasuk: a. Menipu Esau yang lapar untuk memperoleh hak kesulungan, b. menyamar menjadi Esau untuk memperoleh berkat kesulungan dari ayahnya.

Sekalipun demikian, Tuhan tetap menyertai Yakub, bahkan memberkatinya dengan banyak anak, 4 istri dan banyak kambing domba. Namun bahagiakah Yakub dengan semua pencapaiannya itu? Kej. 32:7 menunjukkan bahwa ia sangat takut dan sesak hati ketika akan berjumpa dengan Esau. Mengapa demikian? Ternyata ia dihantui ketakutan akan dosa masa lalu terhadap kakaknya. Bahkan ia memilih berjalan paling belakang dari semua kambing dombanya.

Mungkin di antara Anda ada yang juga pernah mengalami hal itu? Ketika Anda punya banyak hal, namun dihantui oleh rasa bersalah dari masa lalu yang kelam?

Namun, setelah Yakub berjumpa dengan Tuhan, maka ia dapat berdamai dengan masa lalu dan dirinya sendiri. Dan pada akhirnya, Tuhan sendirilah yang memperdamaikan Yakub dengan Esau.

Itulah makna yang tersirat dalam kata "shalom" yang berarti damai sejahtera, yakni ketika seseorang dapat berdamai dengan Tuhan, dengan dirinya sendiri, dan dengan saudara-saudaranya. 
Perubahan dramatis yang dialami Yakub berawal ketika Tuhan memberkati dan memberinya nama baru: Israel.

Saudara-saudaraku, saya tidak tahu apakah ada hal-hal yang menghantui Anda hingga Anda senantiasa tidak tenang. Bawalah dosa-dosamu ke hadapan Yesus Kristus, mintalah Ia membasuh dirimu dari dosa-dosa yang begitu banyak itu, maka hatimu akan tenang.

Ilustrasi

Mari kita kembali ke awal khotbah ini. Alkisah dahulu kala ada seorang pemuda yang berjumpa dengan malaikat di suatu bukit. Malaikat itu berjanji akan mengabulkan satu permohonan dari pemuda itu.

Lalu pemuda itu pulang ke rumah dan berpikir apa yang akan dimintanya. Satu hari, dua hari, tiga hari, sampai seminggu ia belum menemukan jawaban yang pas. Kalau ia minta kekayaan emas segudang, tapi sakit dan mati muda, maka kekayaan akan percuma. Tapi kalau ia minta sehat, tapi miskin, juga percuma. Demikian pikirannya terus mengembara, akhirnya dia menyerah. Pemuda itu lalu kembali menemui malaikat tadi lalu berkata: "Malaikat, tolong bantu aku. Permohonan apakah yang terbaik bagiku?" Malaikat itu tertawa lalu menjawabnya: "Jangan minta kekayaan atau umur panjang atau lainnya. Mintalah hati yang damai apa pun yang terjadi. Itulah yang kamu perlukan."(1) Memang hati yang damai diperlukan oleh siapa saja, baik bupati, walikota, gubernur, pengusaha, eksekutif, ahli pemasaran, petinju, peneliti, guru, dosen, sampai penderita penyakit berat seperti kanker.

Tapi ke manakah kita hendak minta hati yang damai? Hanya Yesus yang sanggup memberikan damai sejahtera sejati yang tidak bisa diberikan oleh dunia. Yesus mengatakan: 
"Damai sejahtera Kutinggalkan bagimu. Damai sejahtera-Ku Kuberikan kepadamu, dan apa yang Kuberikan tidak seperti yang diberikan oleh dunia kepadamu. Janganlah gelisah dan gentar hatimu." (Yoh. 14:27)

Penutup

Demikianlah, mungkin ada di antara Anda yang segera akan menghirup udara bebas, namun ada juga yang masih lama menunggu masa pembebasan. Apapun yang Anda alami dan rasakan, mintalah hati yang damai kepada Bapa di surga. Sekarang, siapa yang ingin hati yang damai dan pengampunan dari Tuhan, mari saya akan mendoakan Saudara.

Amin.

Versi 1.0: 17 oktober 2016, pk. 23:58

$\mathrm{VC}$

Referensi:

(1) kisah ini kalau tidak salah saya baca di Anthony de Mello. Burung berkicau. Jogjakarta: Penerbit Kanisius.

(2) Tony Campolo \& Mary Albert Darling. Connecting like Jesus. San Fransisco: Josey-Bass, 2010. Url: www.joseybass.com 